\title{
Doświadczanie bólu i wiedza na temat jego patomechanizmu oraz metod leczenia w grupie pielęgniarek anestezjologicznych
}

\section{The experience of pain, its pathomechanism and methods of reatment - nurse anaesthetists}

\author{
EWA SZCZECH ${ }^{1}$, MARIOLA RYBKA², ROBERT ŚLUSARZ² \\ ${ }^{1}$ Regionalny Szpital Specjalistyczny im. dr Władysława Biegańskiego w Grudziądzu \\ ${ }^{2}$ Instytut Nauk o Zdrowiu PWSZ we Włocławku
}

DOI: http://dx.doi.org/10.21784/lwP.2017.019

ISSN: 2451-1846

\section{Streszczenie:}

Wstęp. Dolegliwości bólowe pełnią w życiu każdego człowieka funkcję ostrzegawczo - ochronną. Alarmują one organizm przed zagrażającym na skutek choroby czy urazu uszkodzeniem tkanek. Powodują także odruchową oraz behawioralną odpowiedź, mającą na celu zminimalizowanie następstw tego uszkodzenia. Ocena piątego parametru życiowego, jakim jest ból to nieodzowny element oceny stanu zdrowia człowieka.

Cel. Celem prowadzonych badań było poznanie charakteru dolegliwości bólowych występujących w grupie pielęgniarek anestezjologicznych oraz ich wiedzy na temat patomechanizmu oraz metod leczenia bólu.

Materiał i metody. Badania przeprowadzono wśród 70 pielęgniarek anestezjologicznych pracujących w Regionalnym Szpitalu Specjalistycznym im. dr Władysława Biegańskiego w Grudziądzu. W badaniu wykorzystano autorski kwestionariusz ankiety. Na przeprowadzenie badań uzyskano zgodę Komisji Bioetycznej.

Wyniki. Pielęgniarki anestezjologiczne najczęściej doświadczają dolegliwości bólowych kręgosłupa, głowy oraz układu kostno-stawowego. Opisują one 
charakter bólu jako pulsujący, kłujący lub uczucie tępego ucisku. Wśród czynników nasilających ich dolegliwości pielęgniarki najczęściej wskazują nadmierny wysiłek fizyczny oraz stres. W łagodzeniu własnego bólu badane korzystają głównie $\mathrm{z}$ farmakoterapii. Pielęgniarki wśród uznanych i skutecznych metod leczenia dolegliwości bólowych najczęściej wskazywały na farmakoterapię oraz takie metody niefarmakologiczne jak: masaż, krioterapia, stosowanie prądów TENS oraz laseroterapia.

Wnioski. Pielęgniarki anestezjologiczne doświadczają dolegliwości bólowych, które dotyczą najczęściej kręgosłupa, głowy oraz układu kostno-stawowego. Dysponują wiedzą na temat bólu, jego patomechanizmu oraz skutecznych metod jego leczenia.

Słowa kluczowe: ból, pielęgniarka anestezjologiczna, wiedza

\begin{abstract}
:
Introduction. Pain is fundamental to the daily life of every human being as its role is to warn and protect. It warns us about disease or damage to the tissues. It causes bahavioral and instinctive reaction to minimalise the consequences due to the damage. Pain is a crucial component of the reading of vital signs.

Aim. The aim of the study was to understand the nature of pain in the group of nurse anaesthetists and to learn about pain pathomechanism and methods of treatment.
\end{abstract}

Material and methods. The study comprised 70 nurse anaesthetists working in Specialist Hospital of dr Wladyslaw Bieganski in Grudziądz. The consent of Bioethics Commitee was obtained for the following study.

Results. Nurse anaesthetists experience backpain, headaches and osteoarticular disorders. The pain is described as throbbing, stabbing or dull preassure. Physiscal overload and stress are main factors increasing the symptoms. Pharmacotherapy is most often used to relieve the pain and reduce the symptoms.Nurse anaesthetists considered pharmacotherapy as a recognized option for pain relief,together with massage, cryotherapy, electrostimulation and laser therapy as the most effective treatment.

Conclusions. Nurse anaesthetists experience backpain, headaches and osteoarticular disorders. They posses the expertise knowledge how to cope with these disorders.. They are familira with the nature of pain and best methods of treatment. 
Keywords: pain, anaesthetists nurse, expertise knowledge

\section{Wstęp}

Ból jest nie tylko problemem dotykającym pacjentów, ale dotyczy również personelu medycznego a szczególnie pielęgniarek. Jeżeli związany jest on $\mathrm{z}$ działaniami zawodowymi podejmowanymi w środowisku pracy to najczęściej stanowi efekt nieodpowiednich warunków pracy, wykonywania wielu czynności w wymuszonych pozycjach ciała, niedostosowania pomieszczeń do wymogów ergonomii, braku sprzętu do podnoszenia i transportowania chorych. Należy także wspomnieć o czasie pracy i stanie zdrowia pielęgniarek, których średnia wieku w Polsce zbliża się do granicy pięćdziesiątego roku życia.

Międzynarodowe Stowarzyszenie Badania Bólu (International Association for the Study of Pain - IASP) określa ból jako nieprzyjemne doznanie czuciowe i emocjonalne [1,2].

Doznania bólowe można sklasyfikować wg kryterium czasu trwania, mechanizmu powstawania, miejsca występowania oraz etiologii. Walka z dolegliwościami bólowymi była jednym z motorów rozwoju nauk medycznych. Obecnie istnieje wiele sposobów uśmierzania bólu, począwszy od farmakoterapii po metody niefarmakologiczne [3].

Farmakoterapia należy do podstawowych metod leczenia bólu, jednakże zgodnie z zaleceniami Międzynarodowego Stowarzyszenia Badania Bólu, powinna być częścią programu rehabilitacyjnego, uwzględniającego nie tylko zniesienie odczuwanych dolegliwości bólowych, ale również podniesienie poziomu jakości życia pacjentów. Podstawowym i najważniejszym schematem, porządkującym leczenie farmakologiczne bólu jest opracowana przez Światową Organizację Zdrowia w 1986 r. tzw. drabina analgetyczna. Odpowiednio stosowany jej schemat umożliwia skuteczne leczenie dolegliwości bólowych u około $90 \%$ pacjentów. 
Główną zaletą metod niefarmakologicznych w zwalczaniu bólu jest to, że w porównaniu do farmakoterapii powodują znacznie mniej skutków ubocznych i z tego powodu coraz częściej są wdrażane do praktyki. Do niefarmakologicznych metod uśmierzania bólu można zaliczyć: techniki nieinwazyjne, techniki inwazyjne, psychologiczne narzędzia do zwalczania dolegliwości bólowych, fizykoterapię i leczenie manualne [4,5]. Wśród technik nieinwazyjnych uśmierzających dolegliwości bólowe można wyróżnić: TENS, czyli przezskórną elektrostymulację nerwów, akupunkturę oraz wibrację. TENS należy do najczęściej stosowanych metod nieinwazyjnego uśmierzania bólu.

W ramach fizykoterapii optymalne metody walki z dolegliwościami bólowymi to: krioterapia, termoterapia, laseroterapia, masaż i gimnastyka lecznicza [6].

Ból jest zjawiskiem wielowymiarowym, dotykającym poza sferą fizyczną człowieka także i wymiar jego emocjonalnego funkcjonowania. Znacząco bowiem wpływa on na obniżenie samopoczucia i jakości życia. Psychoterapia w kontekście zwalczania dolegliwości bólowych ma na celu zminimalizowanie nasilenia bólu i objawów współwystępujących, takich jak: lęk, zaburzenia snu, naukę skutecznych metod radzenia sobie $\mathrm{z}$ doznaniami bólowymi oraz pozytywne nastawienie chorego $\mathrm{w}$ związku ze stopniową poprawą samopoczucia. Do psychologicznych metod walki z bólem zalicza się przede wszystkim metody autoregulacyjne takie jak: trening autogenny Schultza, wizualizacje, biofeedback, hipnozę. Poza tym stosuje się również edukację oraz techniki behawioralne [7].

Ze względu na wielowymiarowość i subiektywizm charakteryzujący odczuwanie bólu, jego ocena jest procesem złożonym. Istotnego znaczenia nabiera wywiad i przeprowadzenie badania fizykalnego [8]. Najczęściej stosowanymi w codziennej praktyce skalami do oceny bólu są: słowna, numeryczna, wizualnoanalogowa i obrazkowa [9]. Do pomiaru bólu najczęściej wykorzystuje się następujące kwestionariusze: Melzacka, Geriatric Pain Measure, DOLOTest, wskaźnik niesprawności Oswestry (ODI) oraz skalę MIDAS, 
Kwestionariusz Melzacka, inaczej MPQ (McGill pain questionnaire) $[10,11,12,13,14]$.

Korzystanie $\mathrm{z}$ technik kontroli poznawczej powoduje zmniejszenie negatywnych emocji przed, w trakcie i po odczuciu doznań. Badania dowodzą, że brak poczucia kontroli, potęguje odczuwane dolegliwości bólowych oraz prowadzi do osłabienia motywacji i poczucia bezradności [3].

Praca pielęgniarki na oddziale anestezjologii i intensywnej terapii wiąże się z dużym obciążeniem psychicznym i fizycznym. Specyfika oddziału i opieki realizowanej nad pacjentami hospitalizowanymi na OIOM-ie wymaga od personelu pielęgniarskiego nie tylko wysokospecjalistycznej, interdyscyplinarnej wiedzy oraz umiejętności z zakresu anestezjologii, intensywnej terapii, leczenia bólu, medycyny ratunkowej i transplantologii czy zdolności umiejętnego radzenia sobie ze stresem, ale również wytrzymałości fizycznej [15]. Charakter wykonywanej pracy może zatem przyczyniać się one do występowania chorób zawodowych i związanych z nimi rożnego rodzaju dolegliwości bólowych, przede wszystkim dotyczących układu mięśniowo-szkieletowego. Doznania bólowe spowodowane są najczęściej ręcznym transferem pacjentów, aparatury medycznej, częstym przyjmowaniem wymuszonej pozycji ciała podczas wykonywania prac na bloku operacyjnym takich jak: przygotowanie stanowiska do znieczulenia, układanie chorego na stole operacyjnym, nadzorowanie znieczulenia czy przeprowadzanie prac porządkowych po skończonych zabiegach. Oprócz dolegliwości bólowych ze strony układu ruchu w grupie pielęgniarek anestezjologicznych często obserwuje się występowanie bólów głowy. Praca pielęgniarki anestezjologicznej i intensywnej opieki wiąże się $\mathrm{z}$ dużym obciążeniem psychofizycznym i stresem, spowodowanym zaburzeniami snu i rytmu dobowego w przebiegu zmianowej pracy, wykonywaniem wielu czynności pod presją czasu, chronicznym zmęczeniem, czy większym spożyciem kawy, mocnej herbaty $[16,17]$. 
Celem prowadzonych badań było poznanie charakteru dolegliwości bólowych występujących w grupie pielęgniarek anestezjologicznych oraz ich wiedzy na temat patomechanizmu oraz metod leczenia bólu.

\section{Materiał i metody}

W badaniu zastosowano sondaż diagnostyczny oraz metodę szacowania. Do realizacji postawionego celu badań zastosowano kwestionariusz ankiety konstrukcji własnej.

Poza respondentami zgodę na przeprowadzenie badań uzyskano od Dyrekcji Regionalnego Szpitala Specjalistycznego im. dr Władysława Biegańskiego w Grudziądzu oraz Komisji Bioetycznej, funkcjonującej przy CM w Bydgoszczy.

Uzyskane wyniki badań zostały poddane analizie statystycznej.

\section{Wyniki}

Pielęgniarki i pielęgniarze biorący udział $\mathrm{w}$ badaniu pracowali w Oddziale Anestezjologii i Intensywnej Terapii oraz na Oddziale Anestezjologii i Intensywnej Terapii dla dzieci lub dorosłych w Regionalnym Szpitalu Specjalistycznym im. dr Władysława Biegańskiego w Grudziądzu. Respondenci wyrazili zgodę na udział w anonimowym badaniu. Przebadano grupę 70 pielęgniarek i pielęgniarzy. Grupę badaną w przeważającej ilości stanowiły kobiety (44 respondentki) oraz 2 mężczyzn. Średni wiek ankietowanych to 42 lata, jednakże najliczniejszą grupę stanowili respondenci w przedziale wiekowym 41- 45 lat. Zdecydowana większość pielęgniarek posiadała wykształcenie wyższe $(74,3 \%$ badanych). Ponadto 31 pielęgniarek posiadało ukończony kurs kwalifikacyjny $\mathrm{w}$ dziedzinie pielęgniarstwa anestezjologicznego i intensywnej terapii a 6 osób specjalizację w przedmiotowej dziedzinie pielęgniarstwa.

Głównym elementem poddanym analizie był zakres subiektywnych doświadczeń pielęgniarek dotyczących bólu, wiedza na 
temat jego patomechanizmu oraz metod leczenia. Respondenci charakteryzowali własne dolegliwości bólowe, ich rodzaj, charakter, częstość występowania, czas trwania oraz czynniki wyzwalające. Ponadto respondenci wskazywali na rodzaje metod stosowanych w celu uśmierzania bólu.

Występowanie jednej dolegliwości bólowej wskazało 40 osób, dwóch - 27 osób, a trzech - 3 osoby. Łącznie odnotowano 103 odpowiedzi. Zarówno na Oddziale Anestezjologii i Intensywnej Terapii jak i na Oddziale Anestezjologii i Intensywnej Terapii dla Dzieci najwięcej ankietowanych wskazało na występowanie bólów kręgosłupa (42 osoby - 40,8\%), a najmniej bólów kostno-stawowych (27 osób - 26,2\%). Bóle głowy lub migreny podały 34 osoby (33\%).

Respondenci niezależnie od miejsca zatrudnienia wskazali, że występujące u nich dolegliwości bólowe występują najczęściej raz na kilka miesięcy (34 osoby - 48,6 \%) lub kilka razy w miesiącu (23 osoby - 32, 9\%). Najmniej respondentów stwierdziło, że doznania bólowe występują u nich codziennie (3 osoby $-4,3 \%$ ).

Największa liczba ankietowanych zaznaczyła, że dolegliwości bólowe trwają kilka godzin (52 osoby -74,3\%). Kilka dni utrzymujący się ból podało 17 osób (24,3\%). Jeden respondent wskazał, że doznania bólowe trwają $w$ jego przypadku 1 dzień $(1,4 \%)$. Największa grupa respondentów zaznaczyła, że występujące u nich doznania bólowe mają charakter ucisku (44 osoby - 43,6\%) a tylko 4 ankietowanych (4\%), że ból ma charakter stały. Wśród czynników, które wyzwalają odczuwanie dolegliwości bólowych respondenci najczęściej wskazywali nadmierny wysiłek fizyczny (55 osób 46,2\%), stres (31 osób - 26,1\%) lub zmiany pogody (29 osób 24,4\%). Tylko 4 badanych (3,4\%) podkreśliło wpływ zbyt dużej ilości wypijanej kawy na nasilenie bólu.

Natomiast $\mathrm{w}$ zakresie analizy reakcji wywołanych wystąpieniem dolegliwości bólowych respondenci mieli do wyboru sześć stwierdzeń: drażliwość, zaburzenia snu, zaburzenia depresyjne, spowolnienie reakcji, astenię. Najwięcej badanych wskazało na 
spowolnienie reakcji psychoruchowych (50 osób - 39,1\%). W następnej kolejności ankietowani wskazywali drażliwość (38 osób 29,7\%), zaburzenia snu (23 osoby - 18\%), zaburzenia depresyjne (13 osób - 10,2\%). Najmniej badanych wskazało na astenię (4 osoby $3,1 \%)$.

Pielęgniarki stosowały $\mathrm{w}$ walce $\mathrm{z}$ bólem zróżnicowane metody. Najwięcej ankietowanych zaznaczyło, że w łagodzeniu dolegliwości wykorzystują zarówno farmakoterapię jak i metody niefarmakologiczne (52 osoby - 74,3\%). Wyłącznie sięga po leki 1 osób $(24,3 \%)$. Tylko jedna osoba $(1,4 \%)$ wskazała, że w walce $\mathrm{z}$ bólem stosuje wyłącznie metody niefarmakologiczne.

Respondentów poproszono o wskazanie najczęściej stosowanych w odniesieniu do własnej osoby leków przeciwbólowych, które to $\mathrm{w}$ trakcie analizy statystycznej zostały uporządkowane w ramach sześciu grup: NLPZ, paracetamol, opioidy, paracetamol i NLPZ, NLPZ i opioidy oraz opioidy i paracetamol. Niezależnie od miejsca zatrudnienia badani najczęściej wskazywali, że w walce z bólem jako pojedynczy środek stosują leki z grupy NLPZ (36 osób $52,2 \%$ ) oraz paracetamol (18 osób - 26,1\%) Najmniejsza liczba pielęgniarek stosuje opioidy jako pojedynczy środek przeciwbólowy ( 2 osoby $-2,9 \%$ ) lub opioidy w połączeniu z paracetamolem (2 osoby $-2,9 \%)$.

Respondenci wśród najczęściej stosowanych niefarmakologicznych metod leczenia bólu wymieniali metody fizykalne (37 osób - 71,2\%) oraz neuromodulację (10 osób -19,2\%) Tylko jedna osoba wykorzystuje połączenie obu wymienionych wyżej metod. Z kolei po 2 respondentów wskazywało na stosowanie metod psychologicznych i nieinwazyjnych (odpowiednio po 3,8\%).

Najwięcej respondentów na Oddziale Anestezjologii i Intensywnej Terapii oraz na Oddziale Anestezjologii Intensywnej Terapii dla Dzieci stwierdziło, że $\mathrm{w}$ walce $\mathrm{z}$ bólem $\mathrm{z}$ metod niefarmakologicznych najczęściej stosuje metody fizykalne. Jako pojedynczą tę metodę wskazało 37 osób $(71,2 \%)$, a w połączeniu 
z neuromodulacją 1 osoba (1,9\%). Najmniej ankietowanych na wyżej wymienionych oddziałach wskazało, że stosuje metody psychologiczne i nieinwazyjne (po 2 osoby).

Wśród niefarmakologicznych metod leczenia bólu znanych respondentom, najczęściej wymieniane były: krioterapia (70 osób9,1\%), masaż i gimnastyka lecznicza (odpowiednio po 69 osób - po $8,9 \%$ ), laseroterapia i elektroterapia (odpowiednio po 68 osób - po 8,8\%). W najmniejszym zakresie badani wskazywali na Biofeedback termiczny oraz trening autogenny Schulza (odpowiednio po 34 osoby - po $4,4 \%)$.

Respondenci odpowiadając na pytanie o znajomość niefarmakologicznych metod leczenia bólu, zaznaczali po kilka stwierdzeń. Łącznie odnotowano 773 odpowiedzi. Znajomość trzech metod wskazały 2 osoby, pięciu i sześciu metod po 1 osobie, siedem metod - 4 osoby, osiem metod - 11 osób, dziewięć metod - 5 osób, dziesięć metod - 10 osób, jedenaście metod - 3 osoby, a czternaście metod - 33 osoby. W opinii respondentów najskuteczniejsze metody leczenia bólu to farmakoterapia (67 osób -13,9\%), masaż (57 osób 11,9\%), krioterapia (54 osoby - 11,2\%), laseroterapia i TENS (odpowiednio po 53 osoby - po 11,0\%). W najmniejszym zakresie badani wskazywali na Biofeedback EMG, Biofeedback termiczny, wibracje, hipnozę (odpowiednio po 2 osoby - po $0,4 \%$ ).

\section{Dyskusja}

$\mathrm{Na}$ występowanie dolegliwości bólowych wbardzo dużym stopniu są narażeni pracownicy sektora opieki zdrowotnej, w szczególności pielęgniarki. Praca zawodowa pielęgniarek jest zaliczana do najbardziej odpowiedzialnych i najtrudniejszych, stąd odnotowuje się coraz częstsze występowanie problemu obciążenia zawodowego, co przyczynia się do powstawania dolegliwości bólowych układu kostno- stawowego czy bólów głowy [15]. 
W poddanej badaniu grupie 70 pielęgniarek anestezjologicznych, najczęściej występującymi dolegliwościami bólowymi okazały się bóle kręgosłupa, głowy i kostno-stawowe. Najczęstszą przyczyną ich występowania podaną przez respondentów był nadmierny wysiłek fizyczny. Podobne wyniki uzyskali Bilski B. i Sykutera L., którzy prowadzili badania wśród 230 pielęgniarek z czterech poznańskich szpitali, z których większość również zmagała się z bólami kostnostawowymi i bólami kręgosłupa, spowodowanymi obciążeniem fizycznym [4]. Ankietowani biorący udział w prowadzonym badaniu, musieli wykazać się również znajomością różnych metod zwalczania bólu oraz wskazać, które $\mathrm{z}$ nich są $\mathrm{w}$ ocenie najskuteczniejsze i najczęściej stosowane. Respondenci podobnie jak $\mathrm{w}$ badaniach własnych uznali farmakoterapię oraz metody fizykalne (krioterapia, laseroterapia) za najbardziej skuteczne i najchętniej przez nich stosowane $\mathrm{w}$ łagodzeniu bólu. $\mathrm{W}$ badaniach przeprowadzonych przez Kosińską M. i Kułagowską E. i wsp. oraz Dobrowolną P. i Hagnera W również wykazano, że czynne zawodowo pielęgniarki w walce z doznaniami bólowymi najczęściej stosują leki przeciwbólowe [18, 19]. Z kolei Rok S., Wytrążek M. i Bliski B. przebadali grupę 102 pielęgniarek, kontynuujących kształcenie na studiach pomostowych na Akademii Medycznej im. Karola Marcinkowskiego w Poznaniu, które zmagały się z dolegliwościami bólowymi kręgosłupa i u których zastosowano fizykoterapię jako metodę uśmierzenia bólu. Zastosowane metody fizykoterapeutyczne, nie tylko złagodziły dolegliwości bólowe o 4 punkty w skali VAS, ale także zmniejszyły ilość zażywanych przez ankietowanych leków przeciwbólowych [20]. Z kolei Skalska- Izdebska R., Fatyga P., Goraj- Szczypiorowska i wsp. w badaniach dotyczących grupy 40 chorych na reumatoidalne zapalenie stawów, u których zastosowano zabiegi fizykoterapeutyczne, wykazały ich dużą skuteczność w łagodzeniu dolegliwości bólowych. Wspomniane zabiegi wpłynęły także na zmniejszenie obrzęków okołostawowych w podanej grupie pacjentów [21]. 


\section{Wnioski}

1. Pielęgniarki anestezjologiczne doświadczają dolegliwości bólowych, które dotyczą najczęściej kręgosłupa, głowy oraz układu kostnostawowego.

2. Pielęgniarki anestezjologiczne dysponują wiedzą na temat bólu, jego patomechanizmu oraz skutecznych metod jego leczenia.

\section{Bibliografia/Bibliography:}

1. Adamczyk A.: Ból u chorego na nowotwór W: Opieka paliatywna. Buczkowski K., Krajnik M. (red). Wydawnictwo PZWL, Warszawa 2009, 14- 30.

2. Demczyszak I., Wrzosek Z., Sutkowska E.: Współczesna fizykoterapia $\mathrm{w}$ walce $\mathrm{z}$ bólem występującym $\mathrm{w}$ przebiegu wad postawy. Medycyna Manualna 2009, 7, 1-4.

3. Baczewska B., Kropornicka B., Dobrzyńska K.: Strategie radzenia sobie z bólem pacjentów z przewlekłą chorobą internistyczną. Journal of Education, Health and Sport 2016, 6 (11), 281-298.

4. Bilski B., Sykutera L.: Uwarunkowania obciążeń układu ruchu i ich konsekwencje zdrowotne wśród pielęgniarek czterech poznańskich szpitali. Med Pr 2004, 55 (5), 411-416.

5. Maciuk M., Krajewska- Kułak E., Klimaszewska K.: Samoocena występowania zespołów bólowych kręgosłupa u zawodowo czynnych pielęgniarek. Probl Hig Epidemiol 2012, 93 (4), 728738. 
6. Kołłątaj M.: Psychologiczna terapia bólu oparta na dowodach naukowych. Ból 2012, 13 (3), 30-32.

7. Jachimowicz- Wołoszynek D., Jakubowska M., Leźnicka M. Analiza zachowań i przeżyć związanych $\mathrm{z}$ pracą na przykładzie pielęgniarek. Probl Hig Epidemiol 2011, 92 (4), 725732.

8. Czarnecka M., Tylka J.: Cechy osobowości a ocena i strategie radzenia sobie z bólem. Ból 2010, 11, (1), 9.

9. Dębska G., Pasek M., Wilczek- Rużyczka E.: Obciążenia psychiczne i wypalenie zawodowe u pielęgniarek pracujących w różnych specjalnościach zawodowych. Hygeia Public Health 2014, 49 (1), 113-119.

10. Dobrogowski J., Przeklasa- Muszyńska A., Kocot- Kępska M.: Farmakologiczne leczenie bólu przewlekłego. Przew Lek $2010,2,112-120$.

11. Kloc W., Libionka W., Skrobot W i wsp.: Neurochirurgiczne leczenie bólu - część IV. Zabiegi uszkadzające w bólu przewlekłym. Ból 2015, 16 (4), 59-63.

12. Suchocka M.: Ocena warunków pracy pielęgniarek anestezjologicznych. Przedsiębiorczość i Zarządzanie 2012, 13 (11), 109-124.

13. Kurowska K., Ligas I.: Poczucie koherencji a strategie radzenia sobie $\mathrm{z}$ bólem u pacjentów $\mathrm{z}$ przewlekłym bólem neuropatycznym. Anest Ratow 2016, 10, 254-264.

14. Głowacka M., Orzoł A., Soleta A.: Obciążenia zawodowe w praktyce pielęgniarek anestezjologicznych i intensywnej opieki. J Publ Health Nurs Med Rescue 2012, 4, 5-13. 
15. Kułagowska E.: Obciążenie układu mięśniowo szkieletowego podczas prac wykonywanych przez pielęgniarkę anestezjologiczną. Med Pr 2008, 59 (4), 287- 292.

16. Kołłątaj M., Dobrogowski J.: Psychologiczne metody leczenia bólu. W: Leczenie bólu. Wordliczek J., Dobrogowski J. (red). Wydawnictwo PZWL, Warszawa 2011, 191-205.

17. Kosińska M., Kułagowska E., Winkler T. i wsp.: Wymuszone pozycje ciała w pracypielęgniarskiej. Ann UMCS Sect. D 2003, 28 (121), 76-80.

18. Dobrowolna P., Hagner W.: Epidemiologia zespołów bólowych kręgosłupa u pielęgniarek $\mathrm{w}$ szpitalu uniwersyteckim im. A. Jurasza w Bydgoszczy oraz biomechaniczna analiza problemu. Med Biological Sc 2007, 21 (4), 53-63.

19. Kosińska M., Kułagowska E., Winkler T. i wsp.: Wymuszone pozycje ciała w pracypielęgniarskiej. Ann UMCS Sect. D 2003, 28 (121), 76-80.

20. Rok S., Wytrążek M., Bliski B.: Ocena skuteczności ćwiczeń leczniczych w dolegliwościach bólowych dolnego odcinka kręgosłupa u pielęgniarek. Med Pr 2005, 56 (3), 235- 239.

21. Skalska- Izdebska R., Fatyga P., Goraj- Szczypiorowska B. i wsp.: Ocena skuteczności fizykoterapii $\mathrm{w}$ leczeniu reumatoidalnego zapalenia stawów. Young Sport Science of Ukraine 2012, 3, 205215. 